$14^{\text {th }}$ Conf. Agric. Develop. Res., Fac. of Agric., Ain Shams Univ.,

March, 2019, Cairo, Egypt

Special Issue, 27(1), 357 - 365, 2019

Website: http://strategy-plan.asu.edu.eg/AUJASCI/

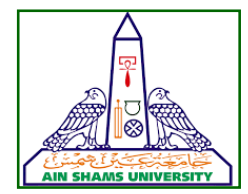

\title{
EFFECT OF ANAEROBIC PROBIOTIC AND/OR BIOLOGICAL ANTITOXIN SUPPLEMENTATIONS ON PRODUCTIVE AND REPRODUCTIVE PERFORMANCE OF LACTATING COWS
}

\author{
Kholif $^{1}$, M.A., Gado ${ }^{1}$ H.M., Metwally ${ }^{1}$ H.M., Abdelgawad ${ }^{2}$ R.M. \\ and Kholif ${ }^{2}$ A.M.
}

1. Animal Production. Dept., Fac. of Agric., Ain Shams Univ., P.O. Box 68- Hadyek Shoubra 11241, Cairo, Egypt

2. Dairy Sciences Dept., National Research Centre, El Buhouth Street, Dokki 12622, Giza, Egypt

*Corresponding author: m_kholif90@yahoo.com

Received 19 September, 2018, $\quad$ Accepted 14 October, 2018

\begin{abstract}
Forty-eight lactating Holstein Friesian cows were utilized to assess impact of supplementing probiotic ZAD (mixture of live bacterial cells and enzymes) compared with T5X (antitoxins product) on some productive, reproductive and antitoxins activity parameters. we have divided the animals to three experimental categories (16 each). The first category, control treatment, was fed basal diet without any supplements. The second category, ZAD treatment, was fed basal diet supplemented with ZAD probiotic (1.1 L/ton). The third category, T5X treatment, was fed basal diet supplemented with T5X antitoxins product $(1.1 \mathrm{Kg} / \mathrm{ton})$. Milk yield was recorded. we have collected and analyzed milk samples, blood samples and feed samples in order to constitutes. Time-interval between calving and fertilizing artificial insemination and pregnancy rate were recorded. The gained outcomes demonstrated that milk yield was significantly raised by ZAD treatment than other treatment. Milk components yield were significantly raised by ZAD probiotic and T5X treatments than control. Blood serum total protein, albumin, globulin, glucose, urea and total lipids were not significantly influenced by treatments. Total aflatoxins in concentrate mixture and aflatoxin $\mathrm{M} 1$ in milk were significantly diminished by ZAD and T5X than control. Number of days between calving and fertilized artificial insemination were diminished by treatments than control. Pregnancy rate was significantly raised by ZAD
\end{abstract}

probiotic than T5X and control treatments, respectively. The overall conclusion of this study illustrated that Probiotic ZAD, potentially, has antitoxins activity leading to reinforcing the productive and reproductive performance of lactating cows.

Keywords: Probiotic, Antitoxins Activity, Milk Yield, Reproductive Performance, Blood, Concentrate Mixture

\section{INTRODUCTION}

Mycotoxins are secondary metabolites created by several of fungi species. These substances are produced fundamentally through five species of fungi (Fusarium sp, Penicillium sp. Aspergillus sp. Claviceps sp. Alternaria sp.) (Xiong et al 2015 and Zouagui et al 2017). Aflatoxins is One of the most common kinds of mycotoxins exist in livestock feeds. Aflatoxins are produced fundamentally in members of Aspergillus flavus, Aspergillus parasiticus, and Aspergillus nomius through the polyketide pathway (Battacone et al 2012 and Xiong et al 2018). Natural forms of aflatoxin, involving forms $B 1, B 2, G 1$, and G2, are mostly found in feeds.

Aflatoxin M1 (AFM1), the monohydroxylated derivate of aflatoxin $B 1$ (AFB1), occurs in milk from dairy cows fed an AFB1 contaminated diet and perhaps subsequently transferred into other dairy products (Battacone et al 2005, Firmin et al 2011 and Xiong et al 2015). Since, AFB1 and AFM1 are 
categorized as a hepatotoxic and carcinogenic substances, and are considered as Group 1 human carcinogens by the International Agency for Research on Cancer (IARC) of the World Health Organization (IARC, 2002), a lot of trials utilizing various manners

to minimize the transfer of aflatoxins from feed to milk involving physical, chemical, and biological manners. Organic and inorganic adsorbents have been utilized to reduce absorbance of AFB1 and transforming as AFM1 to milk (Khattab et al 2009, Xiong et al 2015 and Zouagui et al 2017). furthermore, the antitoxic activity for microorganisms have been documented. some studies indicated that certain strains of bacteria and yeasts have parietal structures capable of binding to mycotoxins (Zouagui et al 2017). According to Chiquette (2009) and $X u$ et al (2017), Probiotics are "live microorganisms that have a positive impact by improving the balance and activity of the intestinal microflora and thereby host health and productivity". For ruminants, probiotics have been shown to be utilized as $\mathrm{pH}$ stabilizing agent, thereby, preventing from acute and sub-acut ruminal acidosis (Nocek and Kautz 2006 and Chiquette et al 2008). Also, probiotics had been demonstrated to raise dry matter intake (2.6 kg/day) and (2.3 $\mathrm{kg} /$ day) milk yield (Nocek et al 2003, Nocek \& Kautz 2006). Similarly, Lehloenya et al (2007) pointed that a $9 \%$ raise in milk yield when a mixture of yeast and Propionibacterium was fed to dairy cows.

on the other hand, Fukuda et al (2006) indicated that a several bacteria with very specified missions in the rumen like a Butyrivibrio fibrisolvens, which produce conjugated linoleic acids (CLA) from linoleic acid, have been suggested as probiotics for ruminants. The probiotic product, $Z A D$, is defined as a biotechnical product made from anaerobic bacteria which convert the polysaccharide into monosaccharide by specific enzymes. ZAD improved nutrients digestibility, live body weight gain and feed conversion of wheat straw in sheep and increased milk production (Gado et al 2009, Salem et al 2011 and Khattab et al 2011)

As mentioned earlier, utilizing bacterial probiotics generates an acidic environment which it injurious to pathogens. Also, the production of bacteriocins by several probiotic strains protects intestinal health and working as adsorbents for mycotoxins (Firmin et al 2011 and Zouagui et al 2017). In this context, the primary goals of this study were evaluating the antitoxic activity for $Z A D \otimes$ probiotic product comparing to the commercial one (T5X). Productive and reproductive performance of lactating cows were evaluated.

\section{MATERIALS AND METHODS}

This study was implemented on El-Gabry farm for animal production, Al-Fayoum Governorate, Egypt. The field experiment was extended for three months from Feb., 2016 to May, 2016. Feed chemical composition, milk chemical composition, blood serum analysis, and feed and milk mycotoxins content analysis were conducted on dairy production department, National research center, Egypt.

\section{Materials}

The purpose of this study is estimating the efficiency of ZAD probiotic product as antitoxic agent. Probiotic ZAD is a mixture of bacteria and exogenous enzymes in liquid formula prepared to supply to ruminants diets. It comprises anaerobic bacteria and mixture of enzymes as cellulase, xylanase, alpha amylase and protease in balanced effective formula. Probiotic ZAD product was compared to a commercial antitoxic product, T5X (mixture from different types of clays as well as vitamins produced by Neovia, vanes cedex, France and imported by Multivita animal nutrition company, Egypt).

\section{Animals, Feeding and management}

In this experiment, we utilized a set of $48 \mathrm{Hol}-$ stein-Frisian cows (120 \pm 3 DIM) in the first season of lactation and averaged $500 \mathrm{Kg}$ body weight. The animals were divided to three equal categories; the first, Control treatment and it fed on the farm basal diet. The second, ZAD treatment and was fed on basal diet supplemented with 1.1 liter of ZAD mixture/ton. The third group, T5X treatment and it was fed on basal diet supplemented with $1.1 \mathrm{Kg} / \mathrm{Ton}$ T5X product. Cows were fed as a group open feed with free access to water. The nutrient requirements were calculated according to NRC, 2001 and recalculated biweekly according to the changing in body weight and milk production. The chemical composition of basal experimental rations is presented in Table 1. 

and reproductive performance of lactating cows

\section{Animals, Feeding and management}

Total of 48 Holstein-Frisian cows (120 \pm 3 DIM) in the first season of lactation and averaged $500 \mathrm{~kg}$ body weight were used in this experiment.

Table 1. Total mixed ration ingredients $(\mathrm{kg} / \mathrm{ton})$ and its chemical composition

\begin{tabular}{|c|c|c|c|}
\hline \multirow[b]{2}{*}{ Ingredient ${ }^{1}$} & \multicolumn{3}{|c|}{ Treatments } \\
\hline & Control & ZAD & T5X \\
\hline Corn silage & 400 & 400 & 400 \\
\hline Alfalfa hay & 110 & 110 & 110 \\
\hline Water & 140 & 140 & 140 \\
\hline Glutofeed $16 \%$ & 75 & 75 & 75 \\
\hline Soybean meal $44 \%$ & 100 & 100 & 100 \\
\hline Yellow corn & 160 & 160 & 160 \\
\hline Limestone & 7 & 7 & 7 \\
\hline Vitamin mixture ${ }^{2}$ & 0.75 & 0.75 & 0.75 \\
\hline Minerals mixture ${ }^{2}$ & 1.5 & 1.5 & 1.5 \\
\hline Sodium bicarbonate & 7 & 7 & 7 \\
\hline T5X (kg/Ton) & 0 & 0 & 1.1 \\
\hline ZAD (L/Ton) & 0 & 1.1 & 0 \\
\hline Total DM offered $(\mathrm{kg} / \mathrm{d})$ & 20 & 20 & 20 \\
\hline \multicolumn{4}{|c|}{ TMR chemical composition \% } \\
\hline DM & \multicolumn{3}{|l|}{84.76} \\
\hline $\mathrm{CP}$ & \multicolumn{3}{|l|}{17} \\
\hline $\mathrm{CF}$ & \multicolumn{3}{|l|}{19} \\
\hline EE & \multicolumn{3}{|l|}{3.1} \\
\hline NDF & \multicolumn{3}{|l|}{30} \\
\hline Forage NDF & \multicolumn{3}{|l|}{23.1} \\
\hline ADF & \multicolumn{3}{|l|}{18.7} \\
\hline NFC & \multicolumn{3}{|l|}{43.9} \\
\hline $\mathrm{Ca}$ & \multicolumn{3}{|l|}{0.38} \\
\hline$P$ & \multicolumn{3}{|l|}{0.24} \\
\hline ME & \multicolumn{3}{|c|}{ 2.42 Mcal /kg } \\
\hline NE I & \multicolumn{3}{|c|}{$1.52 \mathrm{Mcal} / \mathrm{kg}$} \\
\hline NE $g$ & \multicolumn{3}{|c|}{ 1.14 Mcal $/ \mathrm{kg}$} \\
\hline DCAD & \multicolumn{3}{|c|}{$236 \mathrm{mQE} / \mathrm{kg}$} \\
\hline
\end{tabular}

The animals were divided to three equal groups; the first, control treatment and it fed on the farm basal diet. The second, ZAD treatment was fed on basal diet supplemented with 1.1 liter of ZAD mixture/ton. The third group, T5X treatment was fed on basal diet supplemented with 1.1 $\mathrm{kg} /$ Ton T5X product. Cows were fed as a group open feed with free access to water. The nutrient requirements were calculated according to NRC, (2001) and recalculated biweekly according to the changing in body weight and milk production. The chemical composition of basal experimental rations are presented in Table (1).

\section{Feed, milk and blood Sampling and analysis}

During the experiment, represented samples of TMR were collected monthly and analyzed for DM, OM, CP, EE, CF and Ash according to A.O.A.C. (2000) methods. Neutral detergent fiber (NDF) Acid detergent fiber (ADF) were determined according to the procedure of Van Soest et al (1991). Cows were milked 2 times daily at 8 a.m. and 5 p.m. Milk yield for all cows were recorded daily using Delaval milk manager model sortie. Represented milk samples were collected biweekly. Milk constituents of total solids, fat, protein, lactose, solids-non-fat, and ash were determined by Bentley 150 infrared milk analyzer (Bentley Instruments, Chaska, MN, USA). The energy-corrected milk (ECM) equation is commonly used (Tyrrell and Reid, 1965), where: $\operatorname{ECM~}(\mathrm{kg})=(0.3246$ * milk kg $)+$ $(12.86$ * fat $\mathrm{kg})+(7.04$ * protein $\mathrm{kg})$

\section{Mycotoxins analysis in feed and milk}

Determinations of total mycotoxins in feeds were implemented according to AOAC (1995) utilizing HPLC. For AFB1, a C18 Luna II, stainless steel, $5 \mu \mathrm{m}$ column $(150 \times 4.6 \mathrm{~mm}$; Phnomenex, The Netherlands) connected to two high precision pumps (Gynkotek model 300) set at a flow rate of 2 $\mathrm{ml} / \mathrm{min}$ and controlled by a Chromeleon-Gynkotec HPLC software (Softron). The mobile phase consisted of acetonitrile: methanol: water (1: 3: 6, v: v: v). Fluorescence detection was performed with a FP 920 fluorescence detector (Jasco, Japan) set at $360 \mathrm{~nm}$ excitation wavelength and $450 \mathrm{~nm}$ emission wavelength. Milk was analyzed for mycotoxins (AFM1) according to Navas et al (2005) using HPLC (a C18 Luna II, stainless steel, $5 \mu \mathrm{m}$ column (150 x $4.6 \mathrm{~mm}$; Phnomenex, The Netherlands) connected to two high precision pumps (Gynkotek model 300) and set at a flow rate of $1 \mathrm{ml} / \mathrm{min}$ and controlled by a Chromeleon-Gynkotec HPLC software (Softron). Mobile phase was consisted of $2 \%$ acetic acid: acetonitrile: methanol (40:35:25, v/v/v). Fluorescence detection was performed with a FP 920 fluorescence detector (Jasco, Japan) set at $360 \mathrm{~nm}$ excitation wavelength and $430 \mathrm{~nm}$ emission wavelength.

\section{Statistical analysis}

Data collected were subjected to statistical analysis as one-way analysis of variance using SAS (2004) according the following model: 
Where:

$$
Y i j=\mu+T i+e i j
$$

Yij =the observation

$\mu=$ overall mean

$\mathrm{Ti}=$ effect of treatment

eij=experimental error

The significant differences between means of studied groups were tested according to Duncan's New Multiple Ranges Test (Duncan, 1955).

\section{RESULTS AND DISCUSSION}

\section{Blood serum parameters}

Data in Table (2) presented the findings of several blood parameters influenced by ZAD probiotic and T5X antitoxin supplementation to lactating cows' diets.

Also, the findings demonstrated that utilizing ZAD probiotic and T5X antitoxins didn't have any significant impacts on blood serum parameters. It is noted that Globulin value was raised by treatments than control, leading to the same trend with total protein, however, the differences were not significant. It seems that is happened as a reflection for utilizing antitoxins agents, nevertheless it still within the normal range. These findings are in agreement with those reported by Khattab et al (2009). They utilized bentonite as antitoxins agent and they found that plasma total protein was insignificantly $(P>0.05)$ raised by treatment than control. Plasma urea- $\mathrm{N}$ concentration insignificantly raised with utilizing ZAD probiotic than control and T5X treatment. In contrast to these results, blood urea$\mathrm{N}$ was reduced utilizing tafla or bentonite as anti- toxins agents with sheep, goats and buffaloes (Hassona et al 1995, Abou'l Ella, 2007 and Khattab et al 2009). Blood urea $N$ may serve as an indicator of ruminal protein degradability and post ruminal protein supply (Roseler et al 1993). This could explain the increasing in blood urea- $\mathrm{N}$ with using ZAD product which consist of various kinds of enzymes and live bacteria. These compounds lead to raise rumen fermentation activity and ammonia production, thereby blood urea-N. in general, the Urea- $\mathrm{N}$ values for all treatments are still in the normal range $(10-50 \mathrm{mg} / \mathrm{dl})$ as reported by Kaneko (1989). Also, the same trend was noted with total lipid values which increased by treatments than control but this raise was not significant. However, Glucose ratio was slightly reduced by treatments but also it was not significant. Also, liver function enzymes, Alanin aminotransferase $(\mathrm{ALT})$ and aspertat aminotransferase (AST) were not significantly influenced by treatments, meaning that dairy animals were not negatively influenced by utilizing ZAD probiotic and T5X antitoxins agents. These outcomes are in consistent with those reported by Abd El-Baki et al (1988) and Khattab et al (2009). However, Zouagui et al (2017) indicated that utilizing the anti-mycotoxin product (yeast enzymes and clays minerals mixture) had a positive and significant impact on the transaminase activities, liver function of treated animals and total protein, whereas, a significant reduce on reduce of blood urea and total bilirubin were recorded. They attributed these outcomes to the binding properties to mycotoxins of the clay and of the inactivated bacteria and yeast present in the utilized anti-mycotoxin product.

Table 2. Effect of supplemented ZAD probiotic and T5X antitoxin on blood parameters of lactating cows

\begin{tabular}{|l|c|c|c|c|c|}
\hline \multirow{2}{*}{ Parameter } & \multicolumn{3}{c|}{ Diets } & \multirow{2}{*}{ SEM } & P value \\
\cline { 2 - 4 } & Control & ZAD & T5X & \\
\hline Total proteins (g/dL) & 4.13 & 4.61 & 4.99 & 0.289 & 0.165 \\
Albumin (g/dL) & 2.73 & 2.68 & 2.68 & 0.127 & 0.959 \\
Globulin (g/dL) & 1.40 & 1.93 & 2.31 & 0.298 & 0.191 \\
Albumin/globulin & 1.95 & 1.39 & 1.16 & 0.214 & 0.148 \\
Urea-N (mg/dL) & 14.3 & 16.5 & 14.4 & 1.34 & 0.464 \\
Glucose (mg/dL) & 70.8 & 67.2 & 67.5 & 6.54 & 0.911 \\
Total lipids (mg/dL) & 215 & 315 & 291 & 31.0 & 0.114 \\
Alanin aminotransferase (ALT) (Units/L) & 39.5 & 42.1 & 40.9 & 2.22 & 0.714 \\
Aspartate aminotransferase (AST) (Units/L) & 41.8 & 41.9 & 39.1 & 1.23 & 0.254 \\
\hline
\end{tabular}




\section{Milk yield and composition}

Table (3) presented the impact of ZAD probiotic and T5X antitoxins agents on milk yield and milk composition of lactating cows. The outcomes obviously administrated that milk yield was significantly raised by ZAD treatment by $11.2 \%, 12.9 \%$ than control and T5X treatment, respectively, however, no significant difference was shown between T5X treatment and control. Also, milk components yield $(\mathrm{Kg} / \mathrm{d})$ were calculated. Milk total solids yield, solids not fat yield, fat yield, protein yield and lactose yield were significantly raised by ZAD probiotic treatment, however, it reduced significantly by T5X treatment. Milk energy output $(\mathrm{MJ} / \mathrm{d})$ was, also, raised by ZAD probiotic treatment but it negatively influenced by $\mathrm{T} 5 \mathrm{X}$ treatment comparing to control and the differences were significant. Mycotoxins are known to influence dairy cow performances, involving milk production (Zouagui et al 2017). Utilizing antitoxins agents can be help to overcome these negative impacts via inhibiting mycotoxins actions. The outcomes of recent study reported that ZAD probiotic has a potential to inhibit mycotoxins activity as well as raising nutrient intake and digestibility, extent of ruminal fermentation and microbial protein synthesis, Consistent findings were gained by Gado et al (2011) who pointed that ZAD probiotic improve the nutrient digestibility and feed conversion which will led to rais milk production. In addition to, Zouagui et al (2017) utilized clay and the inactivated bacteria and yeasts utilized as ingredients of the antimycotoxin mixture and they found that within the peak of lactation, the treated cows produced an average of 32.9 liters per day of milk against 23 liters for the control cows. In contrary, utilizing antitoxin T5X in this study didn't impact milk yield (table 3), which consistent with the findings gained by various studies showed no impact on milk yield and milk components when they utilized different materials and clays as antitoxins agents (Kutz et al 2009, Queiroz et al 2012 and Xiong et al 2015).

Table 3. Effect of ZAD probiotic and T5X antitoxins agents on milk yield and milk composition of lactating cows

\begin{tabular}{|c|c|c|c|c|c|}
\hline \multirow{2}{*}{ Item } & \multicolumn{3}{|c|}{ Diets } & \multirow{2}{*}{ SEM } & \multirow{2}{*}{$P$ value } \\
\hline & Control & ZAD & T5X & & \\
\hline \multicolumn{6}{|l|}{ Milk production (kg/d) } \\
\hline Yield & $20.4^{\mathrm{b}}$ & $22.7^{\mathrm{a}}$ & $20.1^{\mathrm{b}}$ & 0.30 & $<0.001$ \\
\hline Energy corrected milk & $21.5^{\mathrm{a}}$ & $20.3^{\mathrm{b}}$ & $17.8^{\mathrm{c}}$ & 0.28 & $<0.001$ \\
\hline \multicolumn{6}{|l|}{ Milk components (g/kg) } \\
\hline Total solids & $120.1^{\mathrm{a}}$ & $114.4^{\mathrm{ab}}$ & $108.0^{b}$ & 1.86 & 0.044 \\
\hline Solids not fat & 80.5 & 75.8 & 73.0 & 1.36 & 0.065 \\
\hline Fat & $39.6^{\mathrm{a}}$ & $38.6^{\mathrm{ab}}$ & $35.0^{\mathrm{b}}$ & 0.69 & 0.035 \\
\hline Protein & 36.0 & 34.1 & 32.0 & 0.82 & 0.090 \\
\hline Lactose & 43.3 & 39.6 & 39.0 & 0.77 & 0.053 \\
\hline Milk energy content (MJ/kg) & $2.92^{\mathrm{b}}$ & $3.08^{\mathrm{a}}$ & $2.72^{\mathrm{c}}$ & 0.033 & $<0.001$ \\
\hline \multicolumn{6}{|l|}{ Milk components yield (kg/d) } \\
\hline Total solids & $2.45^{\mathrm{b}}$ & $2.59^{a}$ & $2.17^{\mathrm{C}}$ & 0.034 & $<0.001$ \\
\hline Solids not fat & $1.64^{\mathrm{b}}$ & $1.72^{\mathrm{a}}$ & $1.46^{\mathrm{c}}$ & 0.023 & $<0.001$ \\
\hline Fat & $0.81^{\mathrm{b}}$ & $0.87^{\mathrm{a}}$ & $0.71^{\mathrm{c}}$ & 0.011 & $<0.001$ \\
\hline Protein & $0.73^{\mathrm{b}}$ & $0.77^{\mathrm{a}}$ & $0.64^{\mathrm{c}}$ & 0.010 & $<0.001$ \\
\hline Lactose & $0.88^{\mathrm{a}}$ & $0.90^{\mathrm{a}}$ & $0.78^{b}$ & 0.012 & $<0.001$ \\
\hline Milk energy output (MJ/d) & $0.063^{b}$ & $0.066^{\mathrm{a}}$ & $0.055^{c}$ & 0.001 & $<0.001$ \\
\hline
\end{tabular}

$a, b, c$ : means with different letters differ significantly. $(p<0.01)$ 


\section{Antitoxins activity}

Data in Table (4) presented Probiotic ZAD antitoxic activity comparing to $\mathrm{T} 5 \mathrm{X}$ antitoxins product results

The findings obviously administrate that ZAD probiotic has a positive and significant impact on both total aflatoxins and AFM1. Their concentration was reduced by $50 \%$ and $26.6 \%$ for $Z A D$ and $T 5 X$ treatments than control, respectively. Aflatoxins are secondary metabolites, produced by some species of the genus Aspergillus fungus that contaminate plants and plant products utilized in animals feeding (Cheraghali et al 2007, Iqbal et al 2010, Xiong et al 2015). Aflatoxin B1 is one of the most dangerous aflatoxins. Itis metabolized in animals' rumen to Aflatoxin M1. Different, physical, biological and chemical treatments are utilized to reduce transferring aflatoxins from feed to milk.

According to the outcomes of recent study, ZAD probiotic as one of biological treatments has a potential effect to lessen the aflatoxins from aflatoxins contaminated feed to milk. These outcomes in consistent with those reported by Zouagui et al (2017) who reported that utilizing antitoxin containing inactivated bacteria and yeast reduced the transferring aflatoxin B1 to milk as AFM1.

Table 4. Effect of ZAD probiotic and T5X antitoxin supplementation on TMR total aflatoxins content and milk AFM1 content.

\begin{tabular}{|l|c|c|c|c|c|}
\hline \multirow{2}{*}{ Mycotoxin } & \multicolumn{3}{|c|}{ Treatment } & \multirow{2}{*}{ SEM } & $\begin{array}{c}P \\
\text { value }\end{array}$ \\
\cline { 2 - 5 } & Control & ZAD & T5X & & \\
\hline Total aflatoxins (ppm) & 22.02 & 14.84 & 16.70 & & 0.017 \\
AFM1 (ppm) & 17.52 & 8.76 & 12.85 & 0.77 & \\
\hline
\end{tabular}

\section{Reproduction performance}

The findings in Table (5) presented the effect of probiotic ZAD and T5X antitoxins supplemented to lactating cow's diets on some reproductive parameters.

The findings in table 6 displayed the average required time from calving up to fertilized insemination was reduced by ZAD probiotic treatment, then T5X treatment than control but the differences were not significant. The overall pregnancy rate was significantly increased by antitoxins treatments than control. The highest value was attained by ZAD probiotic treatment and it was $69.2 \%$. These findings are in agreement with those reported by Zouagui et al (2017) who reported that the timeintervals between calving and first artificial insemination ( $\mathrm{Al}$ ) and between calving and fertilizing $\mathrm{Al}$ revealed that these times were shorter for cows got diets supplemented with antitoxins containing inactivated bacteria and yeasts with clays. Also, in this study treated cows also had the highest overall pregnancy rate $(50 \%$ against $27.2 \%$ for the control group). They attributed the poor reproductive performances in non-treated cows to zearalenone aflatoxin present in the mixed feeding ration. Zearalenone is a major toxin produced by the Fusarium molds and its chemical structure is similar to that of the estrogen hormones and this chemical structure is well known by its estrogenic activities. So, it causes several reproductive disorders and different modifications at the genital organs, mainly when its concentration in feed is near to $400 \mathrm{ppb}$ (Whitlow and Hagler, 2000). Depending on this interpretation, the findings of raising pregnancy rate with $Z A D$ probiotic treatment in the recent study may give an initial indication about the role of ZAD probiotic on inhibiting zearalenone toxin. This relation should be investigated within further studies.

Table 5. Effect of ZAD probiotic and T5X supplementation on some reproduction parameters of lactating cows

\begin{tabular}{|l|c|c|c|c|c|}
\hline \multirow{2}{*}{ Item } & \multicolumn{3}{|c|}{ Treatment } & \multirow{2}{*}{ SEM } & $P$ value \\
\cline { 2 - 5 } & Control & ZAD & T5X & \\
\hline $\begin{array}{l}\text { Calving.-FAI } \\
\text { (days) } \\
\text { Pregnancy rate } \\
(\%)\end{array}$ & 77.7 & 66.3 & 73.8 & 7.93 & 0.592 \\
\hline
\end{tabular}

Calving.-FAI (days) ${ }^{*}$ Time-interval between calving and fertilizing artificial insemination

a,b,c: means with different letters differ significantly. $(p<0.01)$.

\section{CONCLUSION}

The outcomes of recent study could assure the outcomes gained by various studies reporting that different species of probiotic bacteria has a potential to have antitoxins activity as well as its a key role in improving the productive and reproductive performance of dairy cows. 

and reproductive performance of lactating cows

\section{REFERENCES}

Abd El-Baki, S.M., Bassuny S.M.; Aiad A.M. and Hassona E.M., 1988. Clays in animal nutrition. 9. In vitro adsorption of ammonia by some local clays and using tafla clay in pelleted complete feed containing urea for sheep. Egyptian J. Nutrition and Feeds, 4 (Special Issue), 7787.

Abou'l Ella, A.A., 2007. Effect of dry yeast and/or bentonite as feed additives on the productive performance of lactating ewes and its offspring's. Egyptian J. Nutrition and Feeds, 10 (1), 81-98.

A.O.A.C., 2000. Official Methods of Analysis. $17^{\text {th }}$ ed. AOAC International, Arlington, VA, USA.

Battacone, G., Nudda A., Palomba M., Pascale M., P. Nicolussi, and Pulina G., 2005. Transfer of aflatoxin B1 from feed to milk and from milk to curd and whey in dairy sheep fed artificially contaminated concentrates. J. Dairy Sci., 88, 3063-3069.

Battacone, G., Nudda A., Rassu S.P.G., Decandia M. and Pulina G., 2012. Excretion of aflatoxin M1 in milk of goats fed a single dose of aflatoxin B1. J. Dairy Sci., 95, 2656-2661.

Cheraghali, A. M., Yazdanpanah H., Doraki N., Abouhossain G., Hassibi M., and Aliabadi S., 2007. Incidence of aflatoxins in Iran pistachio nuts. Food Chem. Toxicol., (45),812816.

Chiquette, J., 2009. The role of probiotics in promoting dairy production. Adv. Dairy Technol., 21, 143-157.

Chiquette, J., Allison M.J., and Rasmussen M.A., 2008. Prevotella bryantii $25 \mathrm{~A}$ used as a probiotic in early-lactation dairy cows: Effect on ruminal fermentation characteristics, milk production, and milk composition. J. Dairy Sci., 91(9), 3536-3543.

Duncan, D.B., 1955. Multiple Range and Multiple F-Tests, Biometrics 11, 1-42.

Firmin, S., Morgavi, D.P., Yiannikouris, A. and Boudra H., 2011. Effectiveness of modified yeast cell wall extracts to reduce aflatoxin B1 absorption in dairy ewes. J. Dairy Sci., 94, 5611-5619.

Fukuda, S., Suzuki Y., Murai M., Asanuma N. and Hino T., 2006. Isolation of a novel strain of Butyrivibrio fibrisolvens that isomerizes linoleic acid to conjugated linoleic acid without hydrogenation, and its utilization as a probiotic for animals. Journal of Applied Microbiology, 100(4), 787-794.

Gado, H.M., Salem, A.Z.M, Odongo N.E. and Borhami B.E., 2011. Influence of exogenous enzymes ensiled with orange pulp on digestion and growth performance in lambs. Animal Feed Science and Technology, 165, 131136.

Gado, H.M., Salem A.Z.M., Robinson P.H. and Hassan, M. 2009. Influence of exogenous enzymes on nutrient digestibility, extent of ruminal fermentation as well as milk production and composition in dairy cows. Animal Feed Science and Technology, 154, 36-46.

Hassona, E.M., Abd El-Baki S.M., Abd El-Khabir A.M., Soliman E.S. and Ahmed M.E., 1995. Clays in animal nutrition. 2- Rations contained sulphuric acid-urea treated rice straw and clays for growing Rahmanni lambs and Zaraibi goats. Proceeding $5^{\text {th }}$ Conference of Animal Nutrition, Ismailia, 1, 207-225.

IARC, 2002. Some traditional herbal medicines, some mycotoxins, naphthalene and styrene. pp.171-175 in "IARC Monograph on the Evaluation of Carcinogenic Risk to Humans". Vol. 82. IARC Scientific Publications, Lyon, France.

Iqbal, S.Z., Paterson, R.R.M., Bhatti I.A. and Asi M.R., 2010. Survey of aflatoxins in chilies from Pakistan produced in rural, semi-rural and urban environments. Food Addit. Contam. Part B Surveill. Jouany J.P., PLM, 383, 46-48.

Kaneko, J.J., 1989. Clinical Biochemistry of Domestic Animals (4 ${ }^{\text {th }}$ Ed.); Academic PressSan Diego, 932, 48-55.

Khattab, H.M., El-Sayed H.M., Mansour A.M., Emara S.A. and Gouda G.A., 2009. Effect of using clay minerals (Bentonite \& Tafla) and baker's yeast on the digestibility and metabolism in high roughage rations of lactating buffaloes. Egyptian Journal of Nutrition and Feeds, 12(3) (Special issue), 59-67.

Khattab, H.M., Gado H.M., Kholif A. E., Mansour A.M. and Kholif A.M., 2011. The potential of feeding goats sun dried rumen contents with or without bacterial inoculums as replacement for berseem clover and the effects on milk production and animal health. Int. J. Dairy Sci., 6, 267-277.

Kutz, R.E., Sampson J.D., Pompeu L.B., Ledoux D.R., Spain J.N., Vazquez-Anon M. and Rottinghaus G.E., 2009. Efficacy of Solis; NovasilPlus; and MTB-100 to reduce aflatoxin M1 levels in milk of early to mid-IHactation dairy 
cows fed aflatoxin B1. J. Dairy Sci.; 92, 39593963.

Lehloenya, K.V., Stein D.R., Allen D.T., G.E., Jones D.A., Aleman M.M., Selk T.G. Rehberger, K.J. Mertz and Spicer L.J., 2007. Effect Of Feeding Yeast and Propionibacteria To Dairy Cows On Milk Yield, And Components And Reproduction. J. Anim. Physiol. Anim. Nutr. (Berl). 2008 Apr; 92(2), 190-202.

Navas, S.A., Sabino M. and Rodriguez-Amaya D.B., 2005. Aflatoxin $M 1$ and ochratoxin $A$ in human milk bank in the city of Sao Paulo, Brazil. Food Addit Contam., 22(5), 457-462.

Nocek, J.E. and Kautz W.P., 2006. Direct-fed microbial supplementation on ruminal digestion, health, and performance of pre- and postpartum dairy cattle. J. Dairy Sci., 89, 260-266.

Nocek, J.E., Kautz W.P., Leedle J.A.Z. and Block E., 2003. Directfed microbial supplementation on the performance of dairy cattle during the transition period. J. Dairy Sci., 86, 331335.

Queiroz, O.C.M., Han J.H., Staples C.R. and Adesogan A.T., 2012. Effect of adding a mycotoxin-sequestering agent on milk aflatoxin M1 concentration and the performance and immune response of dairy cattle fed an aflatoxin B1-contaminated diet. J. Dairy Sci., 95, 5901-5908.

Roseler, D.K., Ferguson J.D., Sniffen C.J. and Herrema J., 1993. Dietary protein degradability effects on plasma and milk urea nitrogen and milk non protein in Holstein cow. J. Dairy Sci., 76, 525-534.

Salem, F.A., A.S. Soliman, Abd El-Mawla S.M. and El-Mahdy M.R., 2011. Effect of some feed additives added to diets of growing sheep on performance, rumen fermentation, blood constituents and carcass characteristics. Benha University, Egypt, Ann. Agric. Sci. Moshtohor, 38, 1885-1904

SAS, 2004. SAS/STAT User's Guide, Version 8, SAS Institute Inc., Cary, NC, USA.

Tyrrell, H.F. and Reid, J.T., 1965. Prediction of the energy value of cow's milk. J. Dairy Sci. 48, 1215-1223.

Van Soest, P.J., Robertson J.B. and Lewis B.A. 1991. Methods for dietary fiber, neutral detergent fiber, and nonstarch polysaccharides in relation to animal nutrition. J. Dairy Sci., 74, 3583-3597.

Xiong, J. L., Wang Y. M., Nennich T.D., Li Y. and Liu J.X., 2015. Transfer of dietary aflatoxin B1 to milk aflatoxin M1 and effect of inclusion of Solis Mos in the diet of dairy cows. J. Dairy Sci., 98, 2545-2554.

Xiong J. L., Wang Y. M., Zhou H. L. and Liu J.X., 2018. Effects of dietary adsorbent on milk aflatoxin M1 content and the health of lactating dairy cows exposed to long-term aflatoxin B1 challenge. J. Dairy Sci., 101, 1-10

Xu H., Huang W., Hou Q., Kwok L., Sun Z., Ma H., Zhao F., Lee Y. and Zhang H., 2017. The effects of probiotics administration on the milk production, milk components and fecal bacteria microbiota of dairy cows. Science Bulletin, 62, 767-774.

Zouagui, Z., Asrar M., Lakhdissi H. and Abdennebi E.H., 2017. Prevention of mycotoxin effects in dairy cows by adding an antimycotoxin product in feed. JMES, 8(10), 37663770. 
المؤتمر الرابع عشر لبحوث التنمية الزراعية،

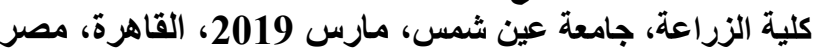

مجلد(27)، عدد (1)، عدد خاص مارس، مارس، 365-357، 2019 2019

Website: http://strategy-plan.asu.edu.eg/AUJASCl/

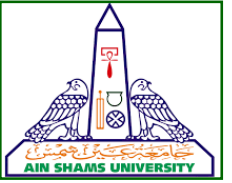

تأثير إضافات البرويايوتيك اللاهوائي مع / أو مضاد السموم البيولوجي علي الآداء الإتتاجي

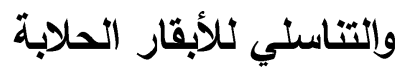

[33]

محمود عبد القادر خليف 1- هاني محمود جادو²- حمدي موسي متولي²- رمضان محمد عبد الجواد3 3 عبدالقادر محمود خليف جمدي

1- قسم الإنتاج الحيواني- كلية الزراعة- جامعة عين شمس - ص.ب 68 حدائق شبرا 1241 - 1124 - القاهرة- مصر

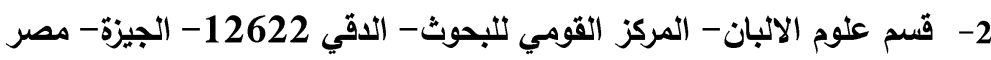

"Corresponding author: ma kholif90@yahoo.com

Received 19 September, 2018,

Accepted 14 October, 2018

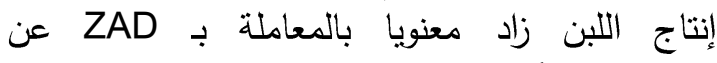

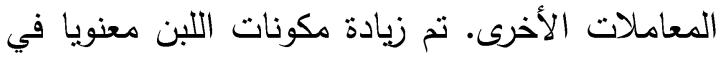
معاملة T5X, ZAD عن المجموعة الأولى. لم ينأثر فئل المين

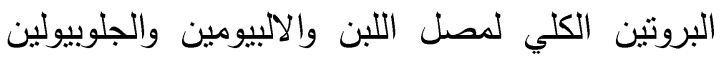

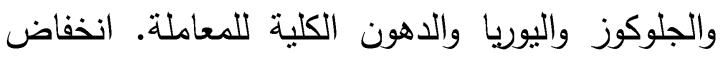
إجمالي الافلاتوكسين في العليقة وافلاتوكسين M1 ولانين

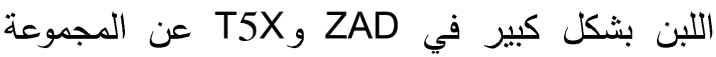

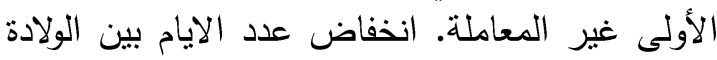

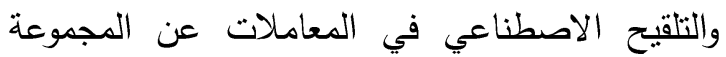

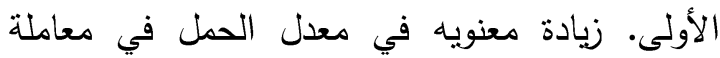

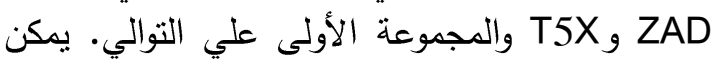

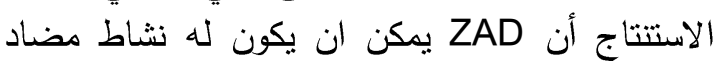
للسموم مما يؤدي الي تحسين الاداء الانتاجي والتناسلي لإني

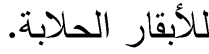

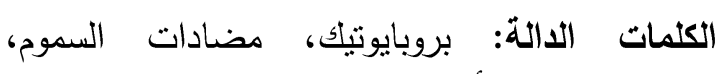
محصول اللبن، الأداء التتاسلي، الدمباء

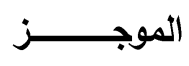

تم استخدام ثماني وأربعين من الابقار الهولثنتين

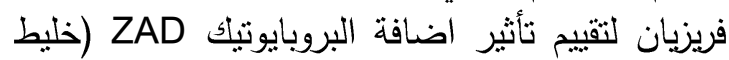

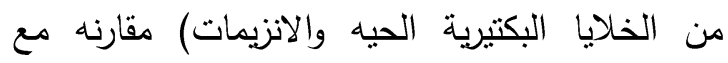

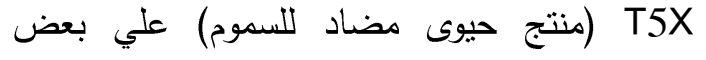
مقاييس النثاط الانتاجي والتناسلي والنشاط المضاد المباد

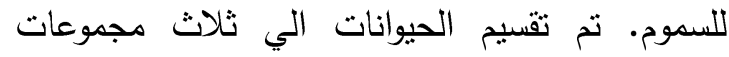

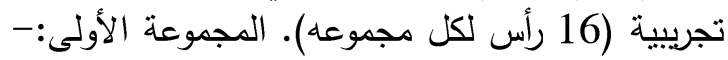

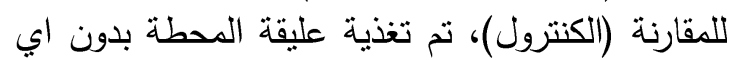

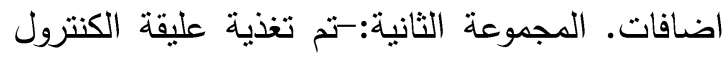

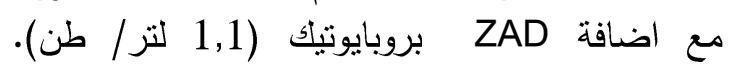

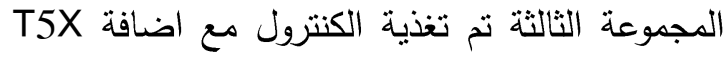
كواقع (1,1 كجم/طن). تم تسجيل انتاج الحليب

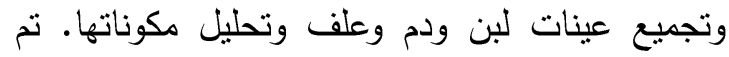

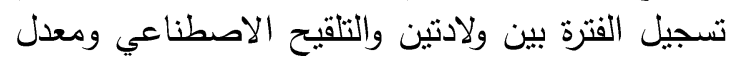

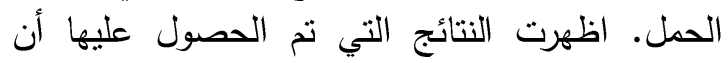

$$
\text { تحكيم: 1.د صبــاح عــلام }
$$

